\title{
Holy Writ and Lay Readers in Late Medieval Europe: Translation and Participation ${ }^{1}$
}

\author{
Sabrina Corbellini and Margriet Hoogvliet
}

\section{Cultural Dynamics in Late Medieval Europe}

Late medieval and early modern Europe is characterized by a significant cultural transformation. As a result of this change, the dichotomy between the categories "religious" and "lay" and "Latin" and "vernacular" dissolved into a more diffuse situation and resulted in lay emancipation with regard to active participation in religious life. One of the most significant manifestations of this cultural transformation was the creation of new "reading communities" in addition to the traditional respublica clericorum, ${ }^{2}$ the learned community of literate intellectuals and religious (secular and regular clergy) who dominated cultural life through their control of Church institutions, schools and universities. Latin, the preferred language by the members of this respublica clericorum, was thus the official (and dominant) language of culture, science and religion. ${ }^{3}$ The new "reading communities" were formed by a non-Latinate, but generally literate, urban laity strongly involved in political, financial and commercial activities. The language of the members of this respublica laicorum, who were showing a growing interest in the organization of cultural activities and in the production of literary texts, was the vernacular, the traditional language of the illiterati and the laity. ${ }^{4}$ The growing textual production in the vernacular involved a challenge from a linguistic and a cultural point of view. It meant that the vernacular was emancipated enough to be used for the production of literature, for the transmission of knowledge, and for religious matters. ${ }^{5}$

This paper is based on the results of the ERC-Starting Grant Research project "Holy Writ and Lay Readers. A Social History of Vernacular Bible Translations in the Late Middle Ages." The project (2008-2013) is funded by the European Research Council in Brussels. Mohrmann (1955) 43. These ideas have been further developed in Corbellini (2013a).

3 For the changing relations between Latin and the vernacular languages, see: Van Uytfanghe (2003).

$4 \quad$ Burke (2004); Warnar (2008).

$5 \quad$ For late medieval vernaculars and vernacularities, see: Copeland (1991); BlumenfeldKosinsky et al. (2002); Somerset-Watson (2003). A European collaborative project (COST

(C) SABRINA CORBELLINI AND MARGRIET HOOGVLIET, 2015 | DOI 10.1163/9789004270848_015 
The development of the European vernacular languages towards a position almost equal to that of Latin was already emerging in France and Italy from the fourteenth century onward. Dante Alighieri wrote his treatise in defence of the vernacular, De vulgari eloquentia, in the early years of the fourteenth century. The French kings Jean II Le Bon and Charles V initiated projects for the promotion of the French of the Île-de-France as the new language for politics and science (clergie). ${ }^{6}$ In spite of the fact that Latin remained the only accepted language for the liturgy, as the arcane language of the divine, the cultural hegemony of Latin, the traditional language of the Church, school and university was no longer indisputable. ${ }^{7}$

This late medieval and early modern cultural transformation has been a much debated topic in European research agenda over the last decades. The focus of this research, however, has been on didactic and moralizing literature, in which themes strictly related to the life and activities of lay readers are discussed: the relations between individuals and groups in the late medieval and early modern urban environment, in particular professional ethics, and family relations. The specific question of the emancipation of the laity, through active readership of religious literature in the vernacular, and in particular the active role of lay people in the transmission and in the production of religious knowledge is still an underestimated subject in medieval research, in spite of the growing interest in the study of religion as cultural manifestation and the significant advances in the study of late medieval religious movements. ${ }^{8}$

Possible reasons for the scarce attention paid to this pivotal aspect of late medieval and early modern cultural life can be identified in the still dominant "protestant paradigm" in the study of religious history, as well as in the leading

Action "New Communities of Interpretation. Contexts, Strategies and Processes of Religious Transformation in Late Medieval and Early Modern Europe"; 2013-2017), lead by the authors of this contribution, will further develop these themes in a European context (see http://www.cost.eu/domains_actions/isch/Actions/IS1301).

$6 \quad$ Walters (2002); Minnis (2009) 11, 36 .

7 This is still a point of discussion: some scholars insist that Latin was the only accepted language for theological discussions (Minnis, 2009), that it was considered by some as an "Adamic language" (Watson (2003) 10), or that the vernacular languages were not accepted as a written language of religion (Hasenohr (2000) 609), but others point at the development of "vernacular theologies" during the 14th and 15th centuries (Gillespie, 2007). As we will see, there is ample evidence for the latter thesis.

8 The study of the Devotio Moderna in the Netherlands and of the Wycliffite and Lollard movement in England, to cite but two examples, has been flourishing since the 1980 s and has produced a particularly high level of scientific results. See for example, Van Engen (2008a); Ghosh (2009). A seminal volume for the research of religious literature in the medieval Low Countries is Mertens (1993). On this topic see also Corbellini (2013a). 
focus in research on the alleged dialectical polarities of high (elite) and low (popular) culture, learned (Latin) and unlearned (vernacular) and ecclesiastical hierarchy (the Church) and the lay believers. ${ }^{9}$ The protestant paradigm implies the explanation of the success of the Reformation in early modern Europe by defining the late medieval Church as "corrupt and moribund" and late medieval religion as a superficial religion tarifiée characterized by a particularly low level of lay commitment and lay participation. ${ }^{10}$ In some studies of medieval Christianity this carelessness of lay believers is linked to the attitude of late medieval Church officials, who focussed on minimum requirements ("the least of the laity"), ${ }^{11}$ and tolerated laxity and even failure. In short the medieval church was "a system which increasingly exhorted specific expectations but was hesitant to define contumacy or disobedience in many but the most obdurate or scandalous cases."12

Moreover, in studies which have paid attention to this aspect, such as the seminal study by Vauchez, ${ }^{13}$ lay religiosity is seen as heavily dependent on clerical inputs as it is "shaped by the distinctions between clergy and laity and by their sometimes acrimonious debates over the social and religious roles proper to each constituent element of Christian society." The main feature of lay spirituality in all its manifestations was the fundamental relationship between the medieval laity and the clergy: the only way to realize the imitatio Christi was the imitatio clerici. ${ }^{14}$ This interpretation of the late medieval Church has, however, been challenged in recent studies which present a different picture: they emphasize, on the one hand, the high expectations of laypeople's religious knowledge and of the religious services available to them and, on the other hand, they stress that laypeople, or at least some of them, were able and willing to meet these expectations. ${ }^{15}$

As John van Engen recently pointed out, the late medieval Church was a much more dynamic world than the one sketched in traditional literature. It was a "carnival of religious options, multiple, competing, contested, coexistent, negotiated, overlapping, local, personally appropriated." It was a world where, as Thomas of Kempen described in his Imitation of Christ, both clergy and laity were more preoccupied with acquiring goods and gratifying desires

\footnotetext{
9 Richmond (1991). Contra this interpretation of lay religious culture: Schreiner (1992); Duffy (1992, 2006); Corbellini (2012b).

10 Gow (2005); Clarke (2008).

11 As in Schmitt (1981).

12 Tanner-Watson (2006) 395.

13 Vauchez (1993).

14 Vauchez (1993) XVIII.

15 Clarke (2008); Rider (2010); Corbellini-Hoogvliet (2013).
} 
pleasing to the flesh than with the care for the spiritual well-being. But at the same time certain laypeople were, as John van Engen describes while referring to Jean Gerson, "so intent in realizing forms of religious intensity which only the professed, in Gerson's view, could truly dedicate themselves to that they generated only inner anxiety or self-righteousness or despondency."16 Both extreme attitudes were possible: the indifferent, the critics and the "reforming zealots," but most of all late medieval religious life was characterized by the vitality of a growing group of believers who "were cracking open niches across a wide and diverse spectrum, finding ways to appropriate religion for themselves." ${ }^{17}$ This vitality brought to the creation of "voluntary associations," such as confraternities, and to a remarkable expansion of preaching activities.

One of the most interesting manifestations of this cultural change was the dramatic increase in the production and the distribution of religious texts in the vernacular, in particular vernacular translations of the Holy Writ, which were accessible to the growing number of members of the respublica laicorum. This process of translation and of diffusion of the biblical text in the vernacular resulted in a significant transformation, which opened up new possibilities to cultural and religious participation of the laity.

The dynamics of the translation process and of its influence on cultural and religious participation of lay believers will be presented and discussed in this contribution. Drawing from French and Italian ${ }^{18}$ sources, this article aims to contribute to the reconstruction of the possibilities for lay readers to access the Scriptures, and of the impact of the presence and the circulation of vernacular bible translations in late medieval religious life. This stress on the situations, responses and outcomes of this process of linguistic and cultural translation implies a significant change of perspective. The relation between clergy and laity, both active in the process of translation, transmission and changing participation, will not be studied in terms of a dominant clergy trying to "bring the laity into line, turning them back into docile sheep,"19 but in terms of processes of negotiation and creative accommodation of meaning. Traces of this process

16 Van Engen (2008b) 266-67, 284.

17 Van Engen (2008b) 269 .

18 The complete corpus of Italian biblical manuscripts consists of $35^{8}$ items. The figures are based on the inventory of Italian Biblical manuscripts published by Chopin-Dinale-Pelosini (1993). For a general introduction to vernacular Bible translations in medieval Italy Leonardi (1998) and Corbellini (2013b). At present there is no exhaustive inventory of manuscripts and early prints with French Bible translations. For a general introduction, see Bogaert (1991), Sneddon (2012) and Hoogvliet (2013).

$19 \quad$ Vauchez (1993) 268. 
can be detected in the textual material written and actively used by both members of the clergy and lay believers.

\section{Translation and Adaptation}

In his prologue to an early fourteenth century abridged Bible in French, the anonymous translator underscores that both the translation and the translator should be reliable in order to preserve the pureness and trustfulness of the text:

He who wants to start the enterprise of translating the Sacred scriptures from Latin into Romance must be careful that that he does not incorporate anything but the pure history, because if he discards the truth he would add lies and those who listen to it would have much with which to reproach him. That is why only those who are sure that they understand Scriptures very well should undertake it. ${ }^{20}$

The argument that the vernacular text is a faithful translation of the Latin original is a recurring element in the prologues to Bibles and other scripture-based texts. As indicated above, during the late Middle Ages, Latin and the vernacular languages had different connotations, but it is striking that the vernacular Bible translations show very little traces of apologetic arguments for the use of a language other than Latin. ${ }^{21}$ This suggests that the conceptualization of vernacular languages was changing and that these were considered as suitable forms of expression for the Biblical text. However, one exception to this observation might be the famous chancellor of the Sorbonne and guardian of orthodoxy, Jean Gerson. He opens his work of devotional instruction La montaigne de contemplation (c. 1400-1401) by affirming that "some people might wonder why I want to write in French rather than in Latin about a subject as elated as

20 "Cil qui vvelt antremetre de traitier diuine escriture et metre de latin an romans se doit mout bien garder que il ni mete riens que ne soit de la vraie istore car se il laissoit la veriteit et il $i$ metoit la mansonge il feroit moult a reprandre de celz qui lantanderoient et pour ceu ne san doit nuls antremetre cil nest bien seurs quil antande bien lescriture." Paris, BnF, Ms fr. 24728 (late 13th-early 14th c.), fol. 1r. For more French examples, see Nobel (2011).

An exception to this general feature should however be noted: in a certain number of prologues the act of translating the bible is "defended" through the reference to Jerome's translating activities. As the Latin bible is a translation of the original Greek and Hebrew texts, the translators of the bible in the vernacular should be seen as "new Jeromes" translating from Latin to the "new languages." 
the contemplative life." 22 But Gerson continues by stating that his text is intended for a very suitable audience: his younger sisters who do not want to marry and who wish to lead a religious life devoted to God instead. Being women and from the laity, they cannot read theological works in Latin. In fact, as Gerson says he has observed many times, certain laypeople are more talented for a life of devotion than clerics. ${ }^{23}$

Thus it becomes clear that Gerson is not really questioning the suitability of the vernacular for religious matters: he uses it in order to promote the aptitude of certain laypeople for a religious life. A similar rhetorical argument can be detected in a fourteenth-century prologue to a French Psalter with elaborate reflections about the translation process from Latin into the vernacular. At first the translator seems to insist on the imperfections of the French (Romance) vernacular:

Because the Romance language is imperfect, and more sufficient than any other complete and perfect language, only good clerics can translate completely from Latin into Romance. ${ }^{24}$

In the treatise about translation techniques from Latin into French that follows, it becomes clear that the translator is not so anxious about the supposed shortcomings of medieval French; rather he is concerned about the imperfections of flawed translations, and uses this argument to insist that it is absolutely necessary for the translator to be an expert in Latin. Towards the end of the prologue the translator indicates unambiguously that daily prayers and recitations of the Psalms are a pleasure to God, both in the Romance vernacular and in Latin, ${ }^{25}$ thus indicating that in his opinion the vernacular languages are suitable for religious activities.

The vernacular was primarily the language of the laity, but during the fifteenth century it was not exceptional for religious men and women to possess

22 "Aucuns se pourront donner merveille pourquoy de matiere haulte comme est parler de la vie contemplative, je veuil escripre en francois plus qu'en latin." Glorieux (1966), 16.

"Et nous l'avons veu et veons par tant d'experiences es sains hermites et en aulcunes femmes qui plus ont pourfité en l'amour de Dieu par ceste vie contemplative que ne font ou ont fait plusieurs grans clers." Glorieux (1966) 18.

"Quar pour tant que langue romance est inperfaite et plus asseiz que nulle autre laingue entieire et perfate, il nest nulz tant soit boin clers que lou laitin puissent translateir entierement en roumant." Paris, BnF, Ms fr. 9572, fol. 1r. Also quoted in Bonnardot (1884) 1-2.

"Sic donc soit en roman soit en laitin tres deuote prieires et orison et que mout plait a Dieu est de dire lou psaltieir ou chesques iour ou biens souuent." Paris, BnF, Ms fr. 9572, fol. 3r. Also quoted in Bonnardot (1884) 10. 
biblical texts in the vernacular, too, and to use them for personal reading and devotion. The mobility of many manuscripts between lay and religious owners is another indication for the growing interaction and exchange between these two groups that in earlier scholarship are often represented as adversary. ${ }^{26}$

Traditionally the translation process of the Bible from Latin into the vernaculars during the late Middle Ages is thought of as a one way process from an active and controlling clergy to a passive and subjected laity. ${ }^{27}$ During the past decade, however, and due to the influence of postmodern theory, this binary transmitter-receiver model and the primacy of Latin have been questioned, and more complex models that include processes of reciprocity and interpenetrability have been proposed instead. ${ }^{28}$

The vernacular translations of the Bible reached wider audiences than the sole respublica clericorum. In this respect, the translation of the Bible during the late Middle Ages involved a process that can be qualified as a "cultural transfer." This concept has been developed theoretically by Michel Espagne, who introduced it for the transfer of philosophical and literary texts between Germany and France during the eighteenth and nineteenth centuries. ${ }^{29}$ While the term cultural transfer has mostly been used for transnational processes, in our view it can also be applied fruitfully for processes of transfer between two different social and linguistic entities; in this case between the mainly Latinate respublica clericorum and the respublica laicorum that relied primarily on the vernacular languages. Espagne also suggests the use of a more complex model than the straightforward transmitter-receiver model, and urges to pay attention to the active role of the context of reception. ${ }^{30}$ Later theoretical elaborations of Espagne's original idea have underscored the reciprocity of cultural transfers, and have proposed to use terminologies as histoire croisée and "cultural exchange."31 These complex and reciprocal models describe very well the translation process of the Holy Writ into the vernacular languages during the Late Middle Ages as well as the interaction between both groups. The historical sources indicate that clerics were not the sole agents of the processes of

26 There are too many examples to quote here in detail. One example from France: Paris, Bibl. de l'Arsenal, Ms 2038 (dated 1466) contains Passion of Christ, according to the narrative of the Gospels. It was copied for "seur Rogiere de Seuauile religieuse de Saint Marceu a Paris." According to a late $15^{\text {th }} \mathrm{c}$. inscription it was later in the hands of Iaqueline $d u$ Hamel.

$27 \quad$ As in Eire $(2007) 84$.

28 Bestul (1996) 11; Kullmann (2009) 8.

29 Espagne (1999); Schmale (2003).

$30 \quad$ Espagne (1999) 23.

31 Werner-Zimmermann (2003); Schilling-Tóth (2006). 
translation of biblical texts into the vernaculars and their dissemination, but that laymen were pleading for translations, they copied the texts themselves, or they paid for the copies made by commercial copyists or printers. ${ }^{32}$

Moreover, as Peter Burke has convincingly suggested, translating implies a process of negotiation between different agents involved in the translation process. ${ }^{33}$ Evidence in the vernacular Bibles suggests, too, that the translation of the biblical text is the result of a process of negotiation between members of the church, in particular Dominicans and Franciscans, and an increasing group of literate lay people, who were explicitly pleading for a direct access to the text of the Scriptures. Traces of this request are still visible in the prologues to the translations. A case in point is the foreword added by the Pisan Dominican Domenico Cavalca to his translation of the Acts of the Apostles:

To satisfy the request of some devout persons (probably the members of one of the confraternities linked to the Dominican monastery) I decided to translate into "common and clear" vernacular the book of the Acts of the Apostles $[\ldots]{ }^{34}$

The canon Guiart des Moulins indicated firstly in his translation of the historical books of the Bible into the French dialect Picard together with the commentaries of Petrus Comestor's Historia scholastica (before 1297), that he made it at the request of "a special friend" and because of "the great pressure of [his] requests to give laypeople the opportunity to understand the ancient scriptures." 35

However, the transition from Holy Writ to lay readers was only possible if a relationship of mutual trust was built between the translators, the readers and the scribes. The importance of this "preliminary agreement" is clearly expressed by a fourteenth-century anonymous Italian translator of a glossed New Testament. Not only does he refer to the necessity for the translator to be an expert in theology, but he requires from those who are eager to copy the text that "they remain faithful to the written text, without making any changes, because every tiny syllable, articles such as $l o$ and $l a[\ldots]$ and words if added or

\footnotetext{
$3^{2}$ Corbellini (2012b).

33 Burke (2007, 2004); Eco (2003).

34 "Volendo, a petizione e per divozione di certe divote persone, recare a volgare comune e chiaro lo divoto libro degli Atti degli Apostoli." Quoted in Barbieri (1998) 300.

"A la requeste dun mien especial ami" and "a la tres grant instance de voz prieres pour faire laies personnes les hystoires des scriptures anciennes.” The Hague, Museum Meermanno, MS 10 B 23, fols. 3v, 4v.
} 
left out can influence the meaning of the sentence more that they would expect." Despite his reservations and warnings this anonymous translator is aware that his translation will most likely be read and copied by less welltrained readers and scribes. His task, therefore, is to educate these new users of the Holy Writ to respect the textual integrity of the translation while copying the text for personal use or while passing it on to others. ${ }^{36}$

It has often been observed that translating is more than the simple linguistic transposition of a text from one language into the other, but that it also involves important cultural and ideological adaptations in order to make the source text functional in the new context of reception. Michel Espagne characterizes this process as "métissages" and observes:

En outre le message transmis doit être traduit du code de références du système d'émission dans celui du système de réception. Cette appropriation sémantique transforme profondément l'objet passé d'un système à l'autre. ${ }^{37}$

Peter Burke for his part uses the terminology "cultural hybridity,"38 and he observes on reception that:

Ideas, information, artefacts and practices are not simply adopted but on the contrary, they are adapted to their new cultural environment. They are first decontextualized and then recontextualized, domesticated or "localized." In a word, they are "translated."39

The addition of paratextual elements, "navigation tools," to the text, such as lists of chapters, a table of contents, rubrics and running titles is a clear strategy in the process of transmission and adaptation of the vernacular biblical text. A clear-structured text is easily accessible, even to non-professional users of the Writ, and makes a selective and effective reading of the text possible as

${ }_{3} 6$ "Guardi a conservare el parlare a lettera secondo che trova scripto et non lo vada mutando però che piccola sillaba et piccolo articulo come sono la lo [...] parole et sillabe hanno molto a variare la sententia più che altri non crede ponendolo o levandole" Perugia, Biblioteca Comunale Augusta, 1086, fol. 3 r. Also quoted in Leonardi (1996) 185 and Corbellini (2012c) 33 .

37 Espagne (1999) 20.

38 Burke (2009a), passim.

39 Burke $(2009 \mathrm{~b}) 70$. For the transformation of texts and messages in the process of transmission, see also Debray (2000). 
the aforementioned Domenico Cavalca states in the introduction to his translation of the Acts of the Apostles:

In order to make the text accessible to those without any knowledge of Latin, I will change at some points the grammatical structure of the sentence and I will also add some explanatory words. Moreover, to grant a better access to this complex and multifaceted text I have divided the text into chapters, which I have listed in the following pages. ${ }^{40}$

This "cutting up of the Bible into specific, usable parts, bound separately"41 could lead to another important feature of the translation and the dissemination of biblical material in the vernacular. Complete bibles, i.e. containing biblical books from Genesis to the book of Revelation, are relatively rare in medieval Europe. Complete translations were available, but more often manuscripts would contain a selection of bible books, in some cases even only a selection of pericopes (for example the beginning of the gospel of John), with a strong focus on the New Testament and more specifically on the passages narrating the Passion of Christ, which was the central point of late medieval religious life. This fragmentation, which contrasts with our modern interpretation of the bible as one coherent text, does not however imply a lack of awareness with regard to the unity of the Holy Writ. It should be interpreted as the result of an active process of selection of textual portions, and as a discontinuous and selective reading practice which is strictly connected with the liturgy, the pivotal "meeting point" in spiritual life of lay and religious. It cannot be a fortuitous coincidence that a very high percentage of vernacular bible manuscripts can be used as a lectionary, either by the arrangement of pericopes following the liturgical calendar or by the addition of liturgical tables or rubrics.

Traditionally these fragmented Bibles are interpreted as part of a strategy by the Church to keep the "real" Bible away from the lay by giving them a substitute. ${ }^{42}$ Our research indicates, however, that the historical reality is more complex; firstly, because abbreviated Bibles were cheaper and thus more affordable, consequently they occurred more often in lower social strata. Secondly, they

$40 \quad$ "Per la moltiplice significatione e intenzione delle parole della Santa Scrittura muto in certi ma pochi luoghi l'ordine delle parole [...] alcuna pongo da me per meglio isporre alcuna parola del detto libro. E perché il detto libro parla di diverse materie e pone molte quistione, acciocché meglio sintenda e possa ciascuno trovare quello che vuole, holla distinta negl'infrascritti capitoli." Quoted in Barbieri (1998) 300.

41 Stallybrass (2002) 47.

42 See Bryan (2008) 31, for a critical discussion of the alleged repressive "here, read this instead" orthodoxy. See also Corbellini (2013b) and Hoogvliet (2013). 
were perceived as real Bibles, because in the manuscripts the abbreviated texts often have as a title "la Bible en francoys," and, thirdly (as the introduction to an abbreviated Bible indicates) it was easier for "simple folk who have not had and who do not have the time to study"43 to understand. Consequently, it would be more logical to interpret these fragments and abbreviated versions as a strategy by certain members of the respublica clericorum to propagate the text of the Bible, instead of censoring and prohibiting it.

According to Régis Debray one of the important consequences of the transmission of a text is a change in hierarchy and in identity. ${ }^{44}$ By looking at the lay audiences of vernacular Bible translations during the fourteenth and fifteenth centuries, we can note that the identity of the lay audiences had already changed, and that this change of identity was expressed by their pressing demand for vernacular bible texts. The consequence of the transmission of the biblical text in the vernaculars was a further acceleration of the religious emancipation of the laity and their participation in religious life.

\section{Participation}

As mentioned in the introduction, laypeople, as members of a respublica laicorum, were active members of "reading communities" taking the form of confraternities or informal private or semi-private networks, which permitted and stimulated activities related to the distribution of vernacular texts and manuscripts. ${ }^{45}$ Lay scribes, users and readers of vernacular bible translations became involved both in a receptive and a productive role in the production, transmission and conservation of religious knowledge. Through these activities, lay people could become channels of transmission of the Holy Writ. Lay people and agents in "webs of interlocution" 46 discussing seminal issues concerning the use and the interpretation of religious knowledge.

The active use of the text enhanced the reader's and the listener's participation in the ritual and in the events narrated in the Scriptures. Through a process of meditation, which stimulated an affective reaction to the narration of the life of Christ, a process of conversion was started: the practice of reading

43 "simples gens qui nont eu et nont lopportunite destudier." La vie de iesucrist, [Lyons, c. 1485-1487], Reims, BM, Inc. 2.

44 Debray (2000) 11.

45 On the concept of "cultural participation," see Rigney (1993) 2. See also Corbellini (2012b) on the role played by confraternities in the plea for vernacular Bible translations.

46 The term was first used by Taylor (1989) 36. 
was a prayerful activity that engaged body and soul in a striving to Christiformitas or Imitatio Christi. By the reading of the gospels, gospel harmonies, or narrations of the passion translated into the vernacular, the reader could better meditate on Christ's life and reach a higher degree of participation in the mystery of the incarnation and of the passion, the death and the resurrection of Christ. This hermeneutic process, which characterizes the "affective theology" of late medieval texts, consists in the psychological identification with the events narrated in the life of Christ. Through this process, the readers were transformed into central characters in the narrated events and were projected into a dimension where the distance in time and space was annihilated: they could stand at the foot of the cross, they could witness the pain and the suffering, they could weep at the moment of death and rejoice at the news of the resurrection. The book they held in their hands was an ever-lasting token of the mystery of the incarnation as announced in the beginning of the Gospel of John (John 1:14: "The Word became flesh and made his dwelling among us. We have seen his glory, the glory of the one and only Son, who came from the Father, full of grace and truth").

A clear example of the role of agents in the distribution of vernacular biblical texts played by laity in late medieval Italy is the very high number of amateur scribes (copisti per passione) ${ }^{47}$ involved in the copying process: saddlers, soap makers, textile workers, shoe-makers, merchants in spices and second hand goods, barbers and dyers. They copied for personal use, but also for use in family and professional networks. In some cases, as in manuscript Florence, Biblioteca Nazionale Centrale Conventi Soppressi B.7.1146, the texts were copied by three members of the same family. On the flyleaf the scribes take care to explain to users of the manuscript that:

The book [was] owned by Giovanni del Nero di Stefano d'Alessandro Cambi [.... One part was written by [his] father Nero, the second by [his] brother Marco and the third by himself, Giovanni [...] The first part is by Marco, the central part and the Penitential Psalms are written by [their] father and at the end the Confession by St Antonino, archbishop of Florence is in [his, Giovanni's] hand in the year 1475 in Certaldo. ${ }^{48}$

The term has been introduced by the Italian historian Branca (1961). On this subject, see Corbellini-Hoogvliet (2013).

48 "Questo libro è di Giovanni del Nero di Stefano d'Alessandro Cambi degli Oportuni di Terma scritto per mano del Nero suo padre una parte e l'altra per mano di Marco suo fratello e l'altra del detto Giovanni et però chi l'acatta renda servigio a chi in esso sè afatichato a scriverlo. In principio di questo libro è di mano di Marcho del Nero Chambi i nel mezzo e salmi 
The manuscripts could thus transform into family books, ${ }^{49}$ which were passed on from generation to generation, as mentioned in a manuscript from Florence, Biblioteca Laurenziana Gaddi, 121, which was copied on 27 October 1431 by Agnolo Carducci. ${ }^{50}$ After his death, in 1434, a member of the family recorded on the flyleaf that "after Agnolo's death the manuscript was to be considered the property of all his heirs." As family books, vernacular bible manuscripts represented a symbol of the unity of the family, transcending chronological lines. The manuscripts, vernacular miscellanies containing texts selected from several exemplars and often compiled in phases and during a long period of time, ${ }^{51}$ accompanied the scribe and his offspring in the process of formation of their religious identities, in the same way that memorial texts helped to create a social and political identity in the changing world of late medieval Italian towns. Manuscripts were, as well as memorial books and family archives, "a cultural patrimony to be preserved, expanded, and transferred to future generations" and they became part the paradigm of "patrimoine."52

The circulation of manuscripts and the subsequent transmission of vernacular bible texts through lay channels can be better understood if it is placed in the context of religious and cultural sociability, i.e. the collaboration between religious and lay believers, which emerges from the study of late medieval religious life in Italian towns. One of the clearest manifestations of this cultural sociability is the correspondence between Mendicant friars (Dominicans, Franciscans and Augustinians) and lay believers, both men and women. This correspondence could take the form of sermons in absentia, i.e. a substitute of the oral transmission of religious knowledge that was connected to spiritual direction and to public preaching activities. ${ }^{53}$ Spiritual directors stress in their letters that it is of the highest importance that spiritual advice is not limited to personal meetings and discussions, but that guidance and supervision should be prolonged by reading and re-reading of letters. The Augustian friar Girola-

penitenziali di mano di Nero nostro padre i nel fine una confessione del Reverendo maestro S. Antonino arciuescovo fiorentino schritta per Giovanni Chanbi per anno 1475 di Ciertaldo essendovi vichario detto Nero di Chambi suo padre M cccc lxxv," Florence, Biblioteca Nazionale Centrale Conventi Soppressi B.7.1146, flyleaf.

The term "family books" (it. libri difamiglia) refers to memorial texts or diaries written by individuals or members of the same family with the primary goal to narrate and to transmit to future generations events related to the history of the family. For a discussion on the definition and function of "family books," see Mordenti (2001) and Ciappelli (2003). For a recent overview of research on Italian libri difamiglia, see Ricci (2005).

5o Fol. 183v.

$51 \quad$ On the textual fragmentation of vernacular bible manuscripts, see section "Translation."

$5^{2} \quad$ Ketelaar (2009).

53 The term sermons in absentia is based on Serventi (2003). 
mo of Siena (1340-1420) stresses this point in one of his letters: "Make arrangements to have these letters with you, if it is possible, and believe strongly that in these writings you will find the right instructions to retrieve the way to salvation." ${ }^{54}$ As noted in the previous discussion on the process of translation, the correspondence is characterized by a full participation of the lay receiver, asking questions and clearly waiting for specific answers to his or her moral and religious dilemmas. In fact, answers to such letters of spiritual guidance have been preserved: when Girolamo da Siena wrote to one of his spiritual daughters, Lucia, to correct her behaviour, which he said was dictated by "vanity and pride," Lucia responded to this disciplina by thanking Girolamo for his letter which had given consolation to her afflicted soul. She went on to describe how she would make use of the letter, by reading the words again and again in order to find, through her faith and through divine grace, the right way to refrain from $\sin .{ }^{55}$ This exchange is evidence of the growing level of religious acculturation among lay believers, who were clearly stimulated by close interaction with members of religious orders. The collaboration resulted also in the writing of reportationes, written accounts of predication activities, which were used as reading material in order to continue in extenso the oral act of predication. The reportationes of the Lenten sermons of the Augustinian Gregorio of Alessandria, held in 1427 in the Florentine church of Santo Spirito, are the work of the Florentine layman Betto d'Andrea Gherardini. Betto was present at all the sermons by Gregorio, where he took notes which he then reworked into an "official" copy. ${ }^{56}$ This "reworking" involved adding references to books which constituted part of "religious capital," such as the Italian translation of the Meditationes vitae Christi and a vernacular version of the Gospels:

Here begins the narration of the Passion following St John the Evangelist, read this morning at Mass. This morning I had no chance to take notes from the passion, as I had run out of wax tables [used to make quick notes during the predication, sc] but I am copying it now from my own text [...] I will write down the passio in Latin and in vernacular. Gregorio

"E inçegnateve d' avere le scripture suo con voi, chi può, e fateve forte concepto di credere che in esse scripture si contenga quello che basti di rasione a condurve per la via di venire a salvamento." Quoted by Gagliardi (2010) 428.

55 Gagliardi (2010) 428-29.

56 The reportationes by Betto d'Andrea Gherardini are preserved in manuscript Florence, Biblioteca Riccardina, 1281. On this subject, see Visani-Bistoni (2009). Betto d' Andrea Gherardini was not alone in writing such notes. For more information about reportationes by lay citizens, especially in Florence, see Zafarana (1968), Howard (2008) and Howard (2006). 
drew only from the gospel of John and did not say anything about the other gospels. ${ }^{57}$

Betto's attitude is a clear answer to the frequent incitements from the pulpit to read the Holy Writ and to memorize the most important passages, to "ruminate" the words and to use them in the process of meditation and visualization which can lead the believer to nullify the physical and chronological distance between the believer and the events narrated in the Scriptures. ${ }^{58}$ One of the clearest expressions of this religious participation through active use of religion texts is the practice of religious meditation by devout laypeople.

\section{Meditation}

At first sight, the daily occupations of the laity seem incompatible with the rhythm and the complete detachment from worldly obligations that were required for a contemplative life. However, it is not entirely correct to state that during the late Middle Ages the Church had never developed a form of spirituality especially adapted to the laity, and that a contemplative life according to the monastic model remained the ideal to be followed. ${ }^{59}$ On the contrary, many vernacular texts based on the Bible seem to suggest to their readers forms of religious reading and meditation that could be performed by laypeople and that permitted them to fulfil their duties in the world, while leading a religious life.

In some vernacular texts the religious value of a life "in the world" is promoted. For instance, in the fourteenth century text La somme le Roi, it is clearly stated that the vita activa is a necessary condition for arriving at the vita contemplativa: "Nobody can come to the contemplative life if he has not been thoroughly tested first in the active life." ${ }^{10}$ Moreover, the text underlines that

"E quivi chomincia il passio di Giovanni vangelista è chantato istamane alla messa. Il quale passio io scritore non apresi per manchamento di tavolille ove scrivevo e feci di scriverlo poi sechondo il testo [...] narerò il passio di San Giovanni e per latino e per volgare, chome Idio mi presterà la grazia, ch'ecchomi ho detto frate Ghrigoro narrò solamento il detto passio e degli altri vangelisti non disse nulla o pocho." Quoted by Visani-Bistoni (2009) 134.

$5^{8}$ On this theme of meditation and rumination, see Corbellini (2012a). For an analysis of the preaching activities of Giovanni Dominici and their references to 'rumination' and meditation, see Debby (2001).

$59 \quad$ As in Hasenohr (1987) 68.

$60 \quad$ "La premiere est voie entrée a la seconde, car nus ne puet venir a la vie contemplative se il n'est premierement bien esprovez en la vie active, si comme dit sainz Greguoires," see Brayer- 
the importance of the vita activa is "to feed God with the flesh of good deeds," 1 a requirement that people living a withdrawn life of contemplation cannot fulfil.

The laity needed to have good and reliable texts in the vernacular recounting the Passion of Christ "according to the Gospels," because a detailed knowledge of this central element of medieval religion was imperative for each Christian. An example of this recommendation to readers can be seen in an early fifteenth-century manuscript "Explanation of the Mass":

A person cannot be a good Christian if he does not think at least one time every day of the good things our Lord has done for him. During Mass one can think about this, because from other thoughts one will not gain any profit from it. The sacrament is done in memory of the blessed suffering and Passion of our Lord, and consequently one should know it well by heart. ${ }^{62}$

Other texts contain more practical instructions for the laity, suggesting to them ways to integrate devotional reading and meditation into their daily life. Firstly it is important to find every day some free time to think of the Passion and to read about it, as is indicated in the following prologue to a fifteenth-century Life of Christ in the French vernacular:

And during one hour of the day take what time you can to think of the Passion without being preoccupied with mundane things; and later during other moments you can read and understand the lessons of this book. And memorize them with patience, because they are indispensable for any person who wants to arrive at a spiritual life. ${ }^{63}$

Leurquin-Labie (2008) 330.

$61 \quad$ "Pestre Dieu de la viande de bones euvres," see Brayer-Leurquin-Labie (2008) 329.

62 "Et nest pas cristian parfait la personne qui ne pense au mains une fois le iour aux biens que nostre seigneur a fais pour luy. A la messe y puet on penser aussi bien come a autre chose que tal ne peut mie prouffiter. Car li sacremens est fais en la remembrance de la benoite souffrance et passion nostre seigneur. Si le doit on bien auoir en memoire." Reims, BM, MS 614 (dated 1403), fol. 129r.

63 "Et une heure du jour prens aucunne espace que tu ayes loisir d'y penser sans toy occuper en aucunes choses mondaines; et apres es autres heures tu pourras lire et entendre les auctoritez et einseignemens de ce livre Et le retien dilligentement en ta memoire. Car elles sont tres necessaires a celuy qui veult venir a vie esperituelle." Paris, Arsenal, Ms 2036, fol. 388r; quoted in Boulton (2000) 58 . 
Other prologues recommend the lay reader to think without interruption about the Passion of Christ during their daily activities:

And similarly in all words and all actions, regardless of the place where you are, regardless of what your position is: on the ground, seated, lying down, eating, speaking, alone or with others; always have your eyes and your mind on your God and our saviour Jesus Christ. ${ }^{64}$

As Maureen Boulton has observed, the instructions in the prologues to the Lives and Passions of Christ in French are simple and constructed in a manner that facilitates memorization. ${ }^{65}$ For instance, a great number of these devotional texts are structured according to the seven days of the week, so that each day has its own theme, connected to the life and Passion of Christ. And, as the author of the prologue to another Life of Christ, written in 1464, claims by following these strictures laypersons can surpass clerics in their spiritual life:

Because, by the frequent meditation of the life of Christ the soul is lifted into a familiarity with Him, trust in Him, and love of Him, while it abhors all other things. Moreover, by this meditation [...] several simple people have known much of God's mysteries and secrets, to which several great clerics have not been able to arrive at all. ${ }^{66}$

\section{Conclusion}

During the late Middle Ages a large group of men of the church, including Jean Gerson, were aware of the religious ambitions of the laity and many of them had witnessed the spiritual successes of several laymen and -women. Lay individuals and groups combining religious ambitious with a life in the world, were accepted and even held in high esteem by their spiritual advisors. In

64 "Et semblablement en toutes paroles et fais En quelque estat et lieu et comment que tu soies Enclin et en estant seant et gesant en mengant ou parlant ou seul ou aueuc aultres Ayes a toute heure ton regard et ton entendement en ton dieu nostre redempteur Ihesucrist." Paris, BnF, Ms fr. 181, fol. viij r.

65 Boulton (2000) 54-56.

66 "Car par la frequente meditacion de la vie diceluy lame si est admenee en vne familiarite confidence et amour diceluy en tant quelle mesprise et contempue toute autre chose. Oultre plus par telle meditacion [...] pluseurs simples gens ont congneu moult des misteres et secres de dieu ausquelz pluseurs grans clers ne sont point parvenus." Paris, BnF, Ms 9587 (dated 1464), fol. ir. 
order to fulfil the religious and theological needs of this group, and in order to incite other laypeople to follow their example, clerics translated (parts of) the Bible into the vernacular, and adapted it to the specific needs of new groups of readers. Through translations, predications and letters of spiritual advice, lay readers and listeners were given the instruments to develop a new cultural and religious capital and new sets of religious values, tailor-made and fitting the specific situation of laypeople, combining worldly and earthly preoccupations with prayer and meditation, the care for their families with the care for the souls and civic responsibilities with religious sociability. Late medieval believers were taking advantage of the fifteenth-century "carnival of religious options" and their plea for a higher level of participation to religious life was in most cases not left unheard: they were exploring possibilities and collaborating with the clergy and members of religious orders in a common search for a more intense religious experience firmly grounded in civic society.

Late medieval religious life was not "moribund" but very much alive. It was one of the most important elements of cultural dynamics, at the centre of a process of negotiation of languages, meanings and values. It was an on-going discussion between Latin and vernacular, between religious and lay, between earth and heaven, and between traditional and new power structures in a society that was in a continuous state of transformation. Religious participation of the laity did not start in $\mathbf{1 5 2 0}$ with Luther and the Reformation, it is a late medieval phenomenon, a world of "voluntary initiatives" connected to the possibility to "personalize" religion and to adapt it to personal lives. ${ }^{67}$

\section{Bibliography}

Barbieri, E., "Cavalca volgarizzatore degli 'Actus Apostolorum," in La Bibbia in italiano tra Medioevo e Rinascimento, ed. L. Leonardi (Florence, 1998), pp. 291-328.

Bestul, Th. H., Texts of the Passion. Latin Devotional Literature and Medieval Society (Philadelphia, 1996).

Blumenfeld-Kosinsky, R., D. Robertson and N. Warren, eds., The Vernacular Spirit. Essays on Medieval Religious Literature (New York, 2002).

Bogaert, P.-M., "La Bible française au Moyen Âge. Des premières traductions aux débuts de l'imprimerie," in Les Bibles en français. Histoire illustrée du Moyen Âge à nos jours, ed. P.-M. Bogaert and -C. Cannuyer (Turnhout, 1991), pp. 14-46.

Bonnardot, F., Le psautier de Metz: texte du XIV siècle (Paris, 1884).

$67 \quad$ Van Engen $(2008 b) 284$. 
Boulton, M., "La Passion pour la Passion: les textes en moyen français," in Le moyen français 44-45 (2000), pp. 45-62.

Branca, V., "Copisti per passione, tradizione caratterizzante, tradizione di memoria," in Studi e problemi di critica testuale. Convegno di Studi difilologia italiana nel centenario della Commissione per i testi in lingua (Bologna, 1961) 69-83.

Brayer, E. and A.F. Leurquin-Labie, eds., "La somme le roi" par frère Laurent (Paris, 2008). Bryan, J., Looking Inward: Devotional Reading and the Private Self in Late Medieval England (Philadelphia, 2008).

Burke, P., Languages and Communities in Early Modern Europe (Cambridge, 2004).

- , "Cultures of Translation in Early Modern Europe," in Cultural Translation in Early Modern Europe, eds. P. Burke and R. Po-chia Hsia (Cambridge, 2007) 7-38.

- Cultural Hybridity (Cambridge, 2009a).

, "Translating Knowledge, Translating Cultures," in Kultureller Austausch:Bilanz und Perspektiven der Frühneuzeitforschung, ed. M. North (Cologne, 20ogb), pp. 69-77.

Chopin, M., M.T. Dinale and R. Pelosini, "Inventario dei manoscritti," in Mélanges de l'Ecole Française de Rome. Moyen Age 105-2 (1993), pp. 863-86.

Ciappelli, G., "Memoria collettiva e memoria culturale. La famiglia fra antico e moderno," in Annali dell'Istituto storico Italo-germanico in Trento 29 (2003), pp. 13-32.

Clarke, P.D., "New evidence of noble and gentry piety in fifteenth-century England and Wales," in Journal of Medieval History 34 (2008), pp. 23-35.

Copeland, R., Rhetoric, Hermeneutics and Translation in the Middle Ages: Academic Traditions and Vernacular Texts (Cambridge, 1991).

Corbellini, S., "Instructing the Soul, Feeding the Spirit and Awakening the Passion: Holy Writ and Lay Readers in Late Medieval Europe," in Shaping the Bible in the Reformation: Books, Scholars and Readers in the Sixteenth Century, eds. B. Gordon and M. McLean (Leyden, 2012a), pp. 15-39.

-, "The Plea for Lay Bibles in Fourteenth and Fifteenth Century Florence. The Role of Confraternities," in Faith's Boundaries: Laity and Clergy in Early Modern Confraternities, eds. N. Terpstra, A. Prosperi and S. Pastore (Turnhout, 2012b), $87-112$.

, "Looking in the Mirror of the Scriptures. Reading the Bible in Medieval Italy," in "Wading Lambs and Swimming Elephants". The Bible for the Laity and Theologians in the Late Medieval and Early Modern Era, eds. W. Francois and A. den Hollander (Leuven, 2012c) 21-40.

- , "Introduction," in Cultures of Religious Reading in the Late Middle Ages, ed. S. Corbellini (Turnhout, 2013a), 1-11.

-, "Vernacular Bible Manuscripts in Late Medieval Italy: Cultural Appropriation and Textual Transformation," in Form and Function of the Medieval Bible, eds. L. Light and E. Poleg (Leiden 2013b), pp. 261-81. 
and M. Hoogvliet, "Artisans and Religious Reading in Late Medieval Italy and Northern France (c. 1400- c. 1520)," in Journal of Medieval and Early Modern Studies 43 (2013), pp. 521-44.

Debby, N., Renaissance Florence in the Rhetoric of two Popular Preachers. Giovanni Dominici (1356-1419) and Bernardino da Siena (1380-1444) (Turnhout, 2001).

Debray, R., Introduction à la médiologie (Paris, 2000).

Duffy, E., The Stripping of the Altars. Traditional religion in England 1400-1580 (New Haven and London, 1992).

__- "Elite and popular religion: the Book of Hours and lay piety in the later middle ages," in Elite and Popular Religion, eds. K. Cooper and J. Gregory (2006), pp. 140-61.

Eco, U., Mouse or Rat? Translation as Negotiation (London, 2003).

Eire, C.M.N., "Early Modern Catholic piety in translation," in Cultural Translation in Early Modern Europe, eds. P. Burke and R. Po-chia Hsia (Cambridge, 2007), pp. 83-100.

Espagne, M., Les transferts culturels franco-allemands (Paris, 1999).

Gagliardi, I., "Tradizione Agostiniana e Tradizione Gesuata," in Storia della direzione spirituale. L'età medievale, ed. S. Boesch Gajano (Brescia, 2010), pp. 425-45.

Ghosh, K., "Wycliffism and Lollardy," in The Cambridge History of Christianity vol. IV: Christianity in Western Europe 1000-1500, eds. M. Rubin and W. Simons (Cambridge, 2009), pp. 433-45.

Gillespie, V., "Vernacular Theology," in Middle English, ed. P. Strohm (Oxford, 2007), pp. 401-20.

Glorieux, P., ed., Jean Gerson. Oeuvres complètes. Volume VII/1: L'oeuvre française (Paris, 1966).

Gow, A., "Challenging the Protestant Paradigm: Bible reading in Lay Urban Contexts of the Later Middle Ages," in Scripture and Pluralism. Reading the Bible in the Religiously Plural Worlds of the Middle Ages and Renaissance, eds. T.J. Heffernan and T.E. Burman (Leiden-Boston, 2005), pp. 161-91.

Hasenohr, G., "Aperçu sur la diffusion et la réception de la littérature de spiritualité en langue française au dernier siècle du Moyen Âge," in Wissensorganisierende und wissensvermittelnde Literatur im Mittalalter, ed. N.R. Wolf (Wiesbaden, 1987), pp. 57-90.

__ - "Les prologues des textes de dévotion en langue française $\left(\mathrm{XIII}^{\mathrm{e}}-\mathrm{XV}^{\mathrm{e}}\right.$ siècles): formes et fonctions," in Les prologues médiévaux, ed. J. Hamesse (Turnhout, 2000), pp. 593-638.

Hoogvliet, M., "The Medieval Vernacular Bible as a Flexible Text: Selective and Discontinuous Reading Practices," in Form and Function of the Medieval Bible, eds. L. Light and E. Poleg (Leiden 2013), pp. 283-306.

Howard, P., "The aural space of the sacred in Renaissance Florence," in Renaissance Florence. A Social History, eds. R.J. Crum and J.T. Paoletti (Cambridge, 2006), pp. 376-93. 
, "Preaching and liturgy in Renaissance Florence," in Prédication et Liturgie au Moyen Âge, eds. N. Bériou and F. Morenzoni (Turnhout, 2008), pp. 313-33.

Ketelaar, E., "The Genealogical Gaze: Family Identities and Family Archives in the Fourteenth to Seventeenth Centuries," in Libraries and Cultural Record 44-1 (2009), pp. 9-28.

Kullmann, D., "Introduction," in The Church and Vernacular Literature in Medieval France, ed. D. Kullmann (Toronto, 2009), pp. 1-11.

Leonardi, L., “'A volerla bene volgarizzare': teoria della traduzione biblica in Italia (con appunti sull' 'Apocalisse')," in Studi medievali 37-1 (1996), pp. 171-201.

—_, ed., La Bibbia in italiano tra Medioevo e Rinascimento. La Bible Italienne au Moyen Âge et à la Renaissance (Florence, 1998).

Mertens, Th., ed. Boeken voor de eeuwigheid. Middelnederlands geestelijk proza (Amsterdam, 1993).

Minnis, A., Translations of Authority in Medieval English Literature: Valuing the Vernacular (Cambridge, 2009).

Mohrmann, C., Latin vulgaire, latin des chrétiens, latin médiéval (Paris, 1955).

Mordenti, R., "I libri di famiglia in Italia, II, Geografia e storia," in Appendice gli Atti del Seminario nazionale "I libri di famiglia in Italia: quindici anni di ricerche" (Rome Tor Vergata, 27-28 June 1997) (Rome, 2001).

Nobel, P., "La traduction biblique," in Translations médiévales. Cinq siècles de traductions en français au Moyen Âge (XI ${ }^{e}-X V^{e}$ siècles). Étude et répertoire, eds. C. Galderisi and V. Agrigoroaei, vol. 1 (Turnhout, 2011), pp. 207-23.

Ricci, A., Mercanti scriventi. Sintassi e testualità di alcuni libri difamiglia fiorentini fra Tre e Quattrocento (Rome, 2005).

Richmond, C., "The English Gentry and Religion c. 1500," in Religious Belief and ecclesiastical careers in late medieval England, ed. C. Harper-Bill (Woodbridge, 1991), pp. 121-50.

Rider, C., "Lay religion and pastoral care in thirteenth century England: the evidence of a group of short confession manuals," in Journal of Medieval History 36 (2010), pp. 327-40.

Rigney, A., "Introduction," in Cultural Participation. Trends since the Middle Ages, eds. A. Rigney and D. Fokkema (1993), pp. 1-12.

Serventi, S., "Sermoni in assenza: l'epistolario di Girolamo da Siena," in La letteratura in forma di sermone: i rapporti tra predicazione e letteratura nei secoli XIII-XVI, eds. G. Auzzas, G. Baffetti and C. Delcorno (Florence, 2003), pp. 79-95.

Schilling, H. and I.G. Tóth, eds., Cultural Exchange in Early Modern Europe, 1400-1700, vol. I: Religion and Cultural Exchange in Europe, 1400-1700 (Cambridge, 2006).

Schmale, W., ed., Kulturtransfer: kulturelle Praxis im 16. Jahrhundert (Innsbruck, 2003).

Schmitt, J.-C., "Du bon usage du Credo," in Faire croire: modalités de la diffusion et de la réception des messages religieux du XIII ${ }^{e}$ au XV $V^{e}$ siècles (Paris, 1981), pp. 337-61. 
Schreiner, K., "Laienfrömmigkeit - Frömmigkeit von Eliten oder Frömmigkeit des Volkes? Zur socialen Verfasstheit laikaler Frömmigkeitspraxis in späten Mittelalter," in Laienfrömmigkiet im späten Mittelalter, ed. K. Schreiner (Oldenburg, 1992), pp. $1-78$.

Sneddon, C.R., "The Bible in French," in The New Cambridge History of the Bible, Vol. 2: From 600 to 1450, ed. R. Marsden and E. A. Matter (Cambridge, Eng., 2012), pp. $251-67$.

Somerset, F. and N. Watson, eds., The Vulgar Tongue: Medieval and Postmedieval Vernacularity (University Park, 2003).

Stallybrass, P., "Books and Scrolls: Navigating the Bible," in Books and Readers in Early Modern England: Material Studies, eds. J. Andersen and E. Sauer (Philadelphia, 2002), pp. $42-79$.

Tanner, N. and S. Watson, "Least of the laity: the minimum requirements for a medieval Christian," in Journal of Medieval History 32 (2006), pp. 395-423.

Taylor, C., Sources of the Self: the Making of the Modern Identity (Cambridge, 1989).

Van Engen, J., Sisters and Brothers of Common Life: the Devotio Moderna and the World of the Later Middle Ages (Philadelphia, 2008a).

"Multiple Options: the World of the Fifteenth-Century Church," in Church History 77-2 (2008b), pp. 257-84.

Van Uytfanghe, M., "Le latin et les langues vernaculaires au Moyen Âge: un aperçu panoramique," in The dawn of the Written Vernacular in Western Europe, eds. Michèle Goyens and Werner Verbeke (Leuven, 2003), pp. 1-38.

Vauchez, A., The Laity in the Middle Ages. Religious Belief and Devotional Practices. Edited and introduced by Daniel E. Bornstein (Notre Dame, 1993).

Visani, O. and M.G. Bistoni, "La bibbia nella predicazione degli Agostiniani. Il caso di Gregorio di Alessandria," in Sotto il cielo delle scritture. Bibbia, retorica e letteratura religiosa (secc. XIII-XVI), eds. C. Delcorno and G. Baffetti (Florence, 20o9), pp. $115^{-37 .}$

Walters, L.J., "The Royal Vernacular: Poet and Patron in Christine de Pizan's Charles V and the Sept Psaumes allégorisées," in The Vernacular Spirit. Essays on Medieval Religious Literature, eds. R. Blumenfeld-Kosinsky, D. Robertson and N. Warren (NewYork, 2002), pp. $145^{-82 .}$

Warnar, G., "Leringhen inden boeken.' De tekst en de drager in de Nederlandse literatuur van de veertiende eeuw," in Spiegel der Letteren 50-2 (2008), pp. 155-71.

Watson, N., "Introduction: King Solomon's Tablets," in The Vulgar Tongue: Medieval and Postmedieval Vernacularity, eds. F. Somerset and N. Watson (University Park, 2003), pp. 1-13.

Werner, M. and B. Zimmermann, "Penser l'histoire croisée: entre empirie et réflexivité," in Annales H.S.S. 57 (2003), pp. 7-34.

Zafarana, Z., "Per la storia religiosa di Firenze nel Quattrocento. Una raccolta privata di prediche," in Studi medievali 9 (1968), pp. 1017-113. 